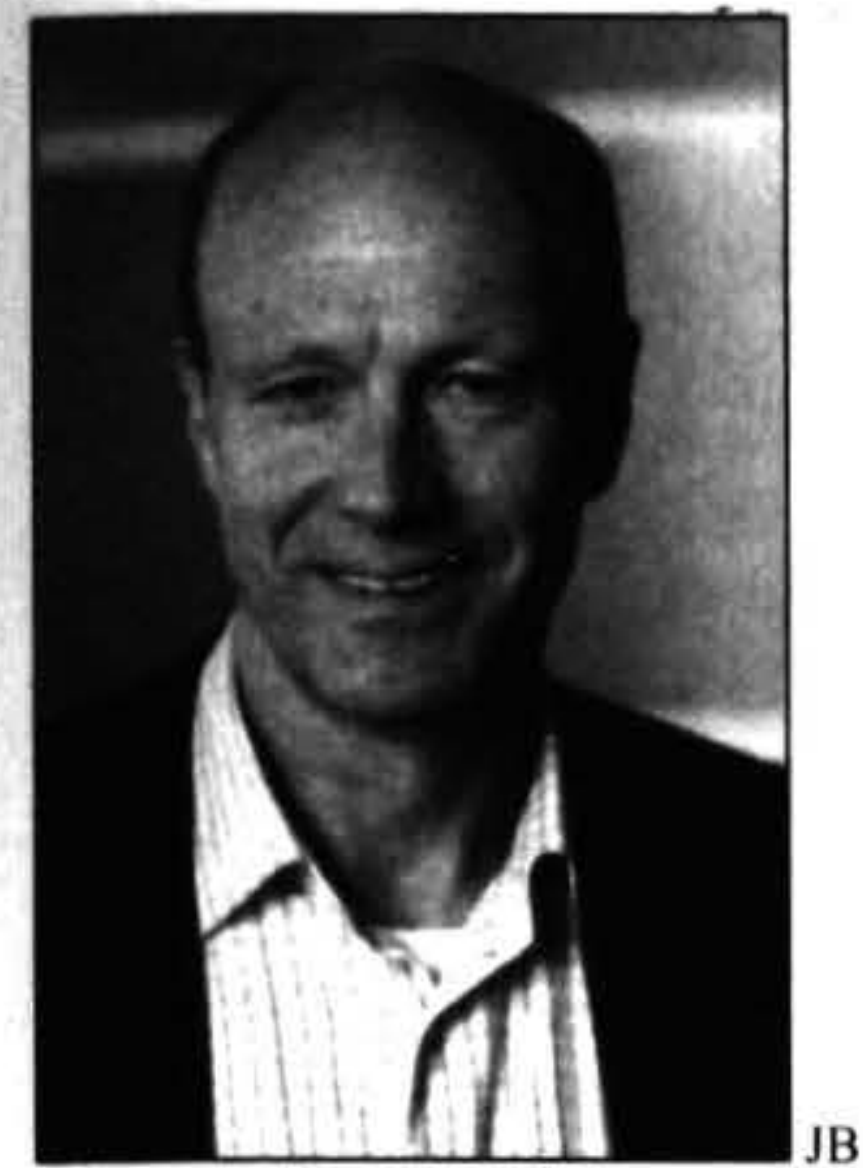

\title{
THE PITFALLS OF MONITORING MINORITY LABOUR MARKET PHENOMENA
}

\author{
James Baines \\ Taylor Baines \& Associates, Christchurch \\ James Newell
}

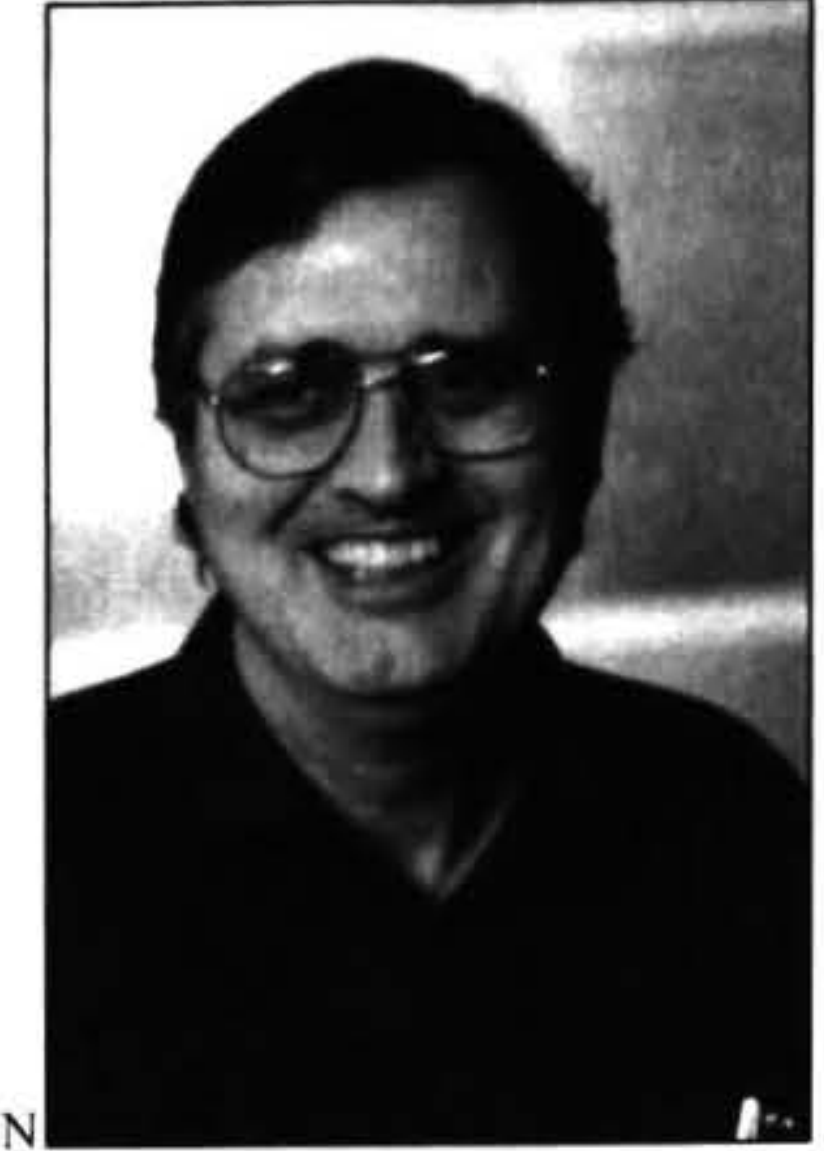

\author{
Monitoring \& Evaluation Research \\ Associates, Wellington
}

\begin{abstract}
Labour markets are in a constant state of change, in both scale and composition. Policy analysts and researchers alike have an interest in tracking such changes over time. Statistics New Zealand is the major source of data on labour markets, and various statistical surveys and census keep us updated at varying frequencies, firom quarterly to 5-yearly. For policy purposes, frequency and timeliness of monitoring data are important. The Household Labour Force Survey is therefore used as the statistical basis for monitoring various aspects of New Zealand labour markets, including trends in employment and unemployment levels. However, comparison of various statistical data sets reveals substantial differences in estimates as data are disaggregated, or as data refer to less universal (i.e. minority) labour market phenomena. Which data set is likely to be more accurate? Is reduced accuracy a casualty of survey sampling. weighting and estimation procedures?
\end{abstract}

\section{Introduction}

Our six-year research programme ${ }^{\prime}$ has been investigating labour markets, and particularly the incidence of multiple job holding in the New Zealand economy since 1981 (Baines and Newell, 2003; Baines et al. 2005; Baines and Newell, 2005; Baines et al. 2006). ${ }^{2}$ The main sources of statistical data for this research have been the 5-yearly census, complemented by the Household Labour Force Survey and other occasional surveys (TUS, SOFIE wave 1).

In the final year of this programme, attention is turning to the assessment of implications of the research; included is a consideration of the implications for social monitoring. Understanding labour markets and the changes occurring in those labour markets is of interest to policy makers and researchers alike. For some time the efforts which have gone into developing and implementing a social monitoring framework in New Zealand have been motivated by the belief that good policy making must be well informed; that the analysis of change and the identification of emerging trends is part of monitoring, which should be linked to the evaluation and coordination of government social policy (Davey, 2006, In Press: 3). Some policies are aimed at the large bulk of labour market participants - macro-economic policy settings to encourage overall job creation, taxation policies, OSH policies, and so on. However, other labour market policies are aimed at more discrete, minor groupings of labour market participants, or people on the fringes of the labour market - policies on minimum wages for youth, unemployment, industry training, getting school leavers into work, retaining older people in the workforce.

For policy purposes, frequency and timeliness of labour market monitoring data are important considerations. Economic management and political imperatives create pressure for regular and frequent updates, as does the need to evaluate social policy interventions.

Although comprehensive in coverage, the five-yearly census is unsatisfactory for short-term monitoring purposes, although still relevant for long-term trend analysis, so long as the comparative data, census by census, are treated with caution. For example, interpretation of trends based on detailed, five-yearly census data must resist the temptation to assume that the timing of peaks, troughs or turning points in trends are accurately portrayed by five-yearly snapshots. Such phenomena (i.e. the timing of peaks and troughs) are likely to be captured more accurately in surveys with greater frequency, such as the HLFS ${ }^{3}$. This requirement points to the importance of establishing comparability between the various sets of statistics, particularly between the census, with its potential to provide a rich picture of detail, and more continuous surveys like the HLFS, which provide less detail but more closely track changes over time.

The Census is carried out in March, every five years, while the HLFS is conducted quarterly. It is reasonable to expect that March quarter results from the HLFS in 
census years should correspond reasonably well with census results for the same output variables. If you wish to know the level of Total Employed or the numbers of Unemployed in New Zealand in March 2001, the results from the 2001 Census and the results from the March 2001 quarter of the HLFS should correspond reasonably closely. If they do not, the obvious question is why not. And if they do not, which results are more appropriate to use policy development or policy evaluation? Comparability between such sources of statistics on the labour market is critical to the credibility of using both sources of data, and provides the basis on which the two can be used together to provide robust monitoring information. As noted, a lack of comparability begs important questions.

Comparability of raw results is perhaps less critical if it can be shown how to reconcile any differences. Making systematic adjustments in order to reconcile quantitative differences at a common point in time would be a method for reconciling census and HLFS data into a common source of monitoring data.

This requires establishing the basis for the differences. Differences could arise as the result of (1) differences in sample composition (sampling error); (2) differences in the wording of the question; (3) differences in datagathering technique; and (4) weighting and estimation procedures.

Besides frequency and timeliness, a social monitoring framework suggests that other considerations are also important for the policy relevance of statistics, both from a statistical perspective (i.e. sampling and weighting) as well as from a perspective grounded in important social policy objectives ${ }^{4}$ (i.e. indicators work and framework). The ability to disaggregate by sex and ethnicity is important to considerations of opportunity and equality, while the ability to disaggregate by age group ${ }^{5}$ is important to considerations of life stage.

\section{Comparing the Labour Market Data Sets}

In this paper we make comparisons between three sets of labour market statistics produced by Statistics New Zealand. The statistical results come from the 2001 Census of Population and Dwellings, the Household Labour Force Survey and the Survey of Families, Income and Employment Dynamics ${ }^{6}$. The distinctive characteristics of each instrument are summarised in the following table.

The analysis reported here is based on comparing data collected at the same time (census and HLFS in March 2001 ) or data collected over the same period (SOFIE wave 1 and four quarters of HLFS covering the period 1 Oct 2002 to 30 Sept 2003).

When reporting its various surveys, Statistics New Zealand generally expresses the results scaled up to represent national-level data. Even though the HLFS surveys only 30,000 individuals, the results are expressed as if every New Zealander of working age had been surveyed. Data from other surveys such as the first wave of the Survey of Families, Income and Employment Dynamics (SOFIE) in 2002/03 are reported in similar fashion.

In this paper we examine the comparability for a variety of labour market indicators at various levels of disaggregation. Taking our cue from the HLFS, in terms of its monitoring role, we examine estimates of Working Age Population, Total Employed and Numbers Unemployed. Because of the particular interests of our research programme, we also include a comparison of estimates of Numbers of Multiple Job Holders.

Table 1: Characteristics of each data-gathering instrument.

\begin{tabular}{|c|c|c|c|c|}
\hline Census survey & Sample size & Timing/frequency & Mode of data gathering & MJH Questions \\
\hline $\begin{array}{l}\text { Survey Of Families, Income } \\
\text { and Employment Dynamics } \\
\text { (SOFIE) }\end{array}$ & $\begin{array}{l}22,000 \text { individuals (Wave } \\
1 \text { ). aged } 15 \text { years and older. } \\
\text { in } 11.500 \text { private } \\
\text { houscholds, sampled } \\
\text { randomly }\end{array}$ & $\begin{array}{l}\text { Wave 1 interviews from I } \\
\text { Oct } 2002 \text { to } 30 \text { Sept } 2003 \text {; } \\
\text { Waves repeated annually } \\
\text { over 12-month periods }\end{array}$ & $\begin{array}{l}\text { Computer-assisted } \\
\text { interviewing. face-to-face. } \\
\text { in respondents homes }\end{array}$ & $\begin{array}{l}\text { Specific questions for each } \\
\text { job }\end{array}$ \\
\hline $\begin{array}{l}\text { Census of Population and } \\
\text { Dwellings (Census) }\end{array}$ & $\begin{array}{l}\text { In } 2001,2.889 .500 \\
\text { individuals aged } 15 \text { years } \\
\text { and older - as complete* a } \\
\text { census as possible }\end{array}$ & $\begin{array}{l}\text { Five-yearly intervals }(.91 . \\
.96,-01,-01, \ldots) \text { in Mareh of } \\
\text { census year }\end{array}$ & $\begin{array}{l}\text { Self-completed census } \\
\text { forms for households and } \\
\text { individual }\end{array}$ & $\begin{array}{l}\text { No specific questions } \\
\text { beyond main job }\end{array}$ \\
\hline $\begin{array}{l}\text { Household Labour Force } \\
\text { Survey (HLFS) }\end{array}$ & $\begin{array}{l}30,000 \text { individuals aged } 15 \\
\text { years and older, in } 16,000 \\
\text { private houscholds }\end{array}$ & $\begin{array}{l}\text { Quarterly, since October } \\
19 \times 5\end{array}$ & $\begin{array}{l}\text { First interview face-to-face: } \\
\text { subsequent interviews by } \\
\text { telephone }\end{array}$ & $\begin{array}{l}\text { No specific questions } \\
\text { beyond main job }\end{array}$ \\
\hline
\end{tabular}

* Even the official census is subject to a very small degree of under-counting. due to non responses. In the past two censuses, the level of undercounting has been $1.6^{\circ} \circ(1996)$ and $2.2^{\circ} \circ(2001)$ 
Comparing Census (March 2001) Data with HLFS (March 2001) Data

The first comparison is between the Census and one sample survey, the HLFS. The Working-Age Population covered by the Census in 2001 was just under 3 million

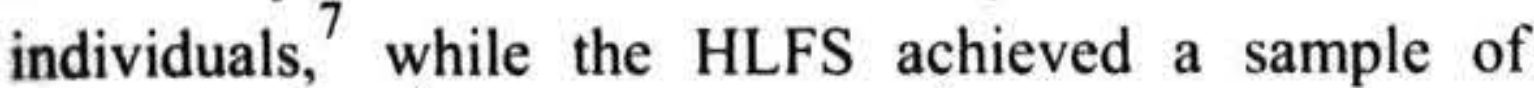
approximately 30,000 individuals. $^{8}$ The purpose of the HLFS is "to produce each quarter, a comprehensive range of statistics relating to the employed, the unemployed and those not in the labour force who comprise New Zealand's working-age population." Tables 2 and 3 summarise Statistics New Zealand estimates of Working Age Population, Total Employed, Numbers Unemployed and Multiple Job Holders, based on the Census (March 2001) and the March 2001 Quarterly HLFS. Table 2 presents absolute numbers (estimates based on counts) while Table 3 expresses the HLFS estimates as a \% of the corresponding Censusbased estimates.

The data are presented in aggregate, as well as disaggregated by sex, age band and ethnicity.

\section{Comparing SOFIE Wave 1 (Oct02/Sept03) Data with HLFS (Oct02/Sept03) Data}

The second comparison is between two sample surveys the Survey of Families, Income and Employment Dynamics (SOFIE) and the HLFS. The primary objectives of SOFIE are to look at how New Zealanders' circumstances and lifestyles change over time, and the factors that influence those changes. Wave 1 of SOFIE collected information about work, family and household circumstances and income. This information will be used to help design and evaluate government policy on income support, employment, education, training, retirement provision and family support. ${ }^{10}$ Indeed, these are precisely the kinds of social policy issues which require the capacity to monitor accurately minority labour market phenomena, since each has a focus that, at any given time, is most likely to apply to a relatively minor proportion of the working age population.

Tables 4 and 5 summarise estimates of Working Age Population, Total Employed and Numbers Unemployed, based on the average Statistics New Zealand estimates for four consecutive quarters of the HLFS ending 30 September 2003 and the Statistics New Zealand estimates from Wave 1 of SOFIE based on responses collected between 1 October 2002 and 30 September 2003. Table 4 presents absolute numbers (estimates based on counts) while Table 5 expresses the SOFIEbased estimates as a $\%$ of the corresponding HLFSbased estimates.

As before, the data are presented in aggregate, as well as disaggregated by sex, age band and ethnicity.

No comparisons have been made for estimates of multiple job holders in the absence of HLFS data on multiple job holding for this period.

It is evident from examining Table 3 that comparability between HLFS-based estimates and Census-based estimates is strongest at the highest levels of aggregation (i.e. for All New Zealanders in aggregate, or disaggregated by sex - a binary split) and for indicators that are most universal (i.e. Working Age Population and Total Employed).

Table 2: Statistics New Zealand estimates of labour market indicators - Census and HLFS.

\begin{tabular}{|c|c|c|c|c|c|c|c|c|}
\hline & \multicolumn{2}{|c|}{$\begin{array}{l}\text { Working Age } \\
\text { Population }\end{array}$} & \multicolumn{2}{|c|}{ Total Employed } & \multicolumn{2}{|c|}{ Unemployed } & \multicolumn{2}{|c|}{$\begin{array}{l}\text { Multiple Job } \\
\text { Holders }\end{array}$} \\
\hline & $\begin{array}{c}\text { Census } \\
\text { (March } \\
01)\end{array}$ & $\begin{array}{c}\text { HLFS } \\
\text { (March } \\
01)\end{array}$ & $\begin{array}{c}\text { Census } \\
\text { (March } \\
01)\end{array}$ & $\begin{array}{c}\text { HLFS } \\
\text { (March } \\
01)\end{array}$ & $\begin{array}{c}\text { Census } \\
\text { (March } \\
01)\end{array}$ & $\begin{array}{c}\text { HLFS } \\
\text { (March } \\
\text { 01) }\end{array}$ & $\begin{array}{c}\text { Census } \\
\text { (March } \\
\text { 01) }\end{array}$ & $\begin{array}{c}\text { HLFS } \\
\text { (March } \\
\text { 01) }\end{array}$ \\
\hline $\begin{array}{l}\text { All New } \\
\text { Zealanders }\end{array}$ & $2,889,534$ & 2909,000 & $1,727,268$ & $1,806,300$ & 139,908 & 109,100 & 174,435 & 67,900 \\
\hline $\begin{array}{l}\text { By sex: } \\
\text { Women } \\
\text { Men }\end{array}$ & $\begin{array}{l}1,501,218 \\
1,388,319\end{array}$ & $\begin{array}{l}1,494,300 \\
1,414,700\end{array}$ & $\begin{array}{l}804,312 \\
922,962\end{array}$ & $\begin{array}{l}816,400 \\
990,000\end{array}$ & $\begin{array}{l}70,170 \\
69,738\end{array}$ & $\begin{array}{l}49,700 \\
59,400\end{array}$ & $\begin{array}{l}86,355 \\
88,083\end{array}$ & $\begin{array}{l}39,800 \\
28,000\end{array}$ \\
\hline $\begin{array}{l}\text { By age band: } \\
15-24 \text { yr olds } \\
25-44 \text { yr olds } \\
45-64 \text { yr olds } \\
65+\text { yr olds }\end{array}$ & $\begin{array}{c}505,071 \\
1,109,253 \\
824,790 \\
450,420\end{array}$ & $\begin{array}{l}529,700 \\
1,121,000 \\
831,400 \\
426,900\end{array}$ & $\begin{array}{c}271,035 \\
820,335 \\
585,996 \\
49,947\end{array}$ & $\begin{array}{c}294,000 \\
871,400 \\
607,900 \\
33,000\end{array}$ & $\begin{array}{c}56,403 \\
57,612 \\
25,086 \\
813\end{array}$ & $\begin{array}{l}44,200 \\
41,000 \\
23,600 \\
. .\end{array}$ & $\begin{array}{c}24,462 \\
75,888 \\
67,887 \\
6,216\end{array}$ & $\begin{array}{l}\text { No data } \\
\text { No data } \\
\text { No data } \\
\text { No data }\end{array}$ \\
\hline $\begin{array}{l}\text { By ethnicity: } \\
\text { European/Pakeha } \\
\text { Maori } \\
\text { Pacific Peoples }\end{array}$ & $\begin{array}{c}2,114,181 \\
329,685 \\
130,137\end{array}$ & $\begin{array}{l}2,271,700 \\
294,600 \\
139,000\end{array}$ & $\begin{array}{c}1,360,563 \\
185,757 \\
71,172\end{array}$ & $\begin{array}{c}1,463,700 \\
164,300 \\
74,200\end{array}$ & $\begin{array}{l}72,264 \\
37,488 \\
13,260\end{array}$ & $\begin{array}{c}64,700 \\
22,500 \\
9,400\end{array}$ & $\begin{array}{c}150,921 \\
13,431 \\
2,694\end{array}$ & $\begin{array}{l}\text { No data } \\
\text { No data } \\
\text { No data }\end{array}$ \\
\hline
\end{tabular}


Table 3: Comparing HLFS-based estimates with census-based estimates.

\begin{tabular}{|c|c|c|c|c|c|}
\hline & & $\begin{array}{l}\text { Working Age } \\
\text { Population }\end{array}$ & Total Employed & Unemployed & Multiple Job Holders \\
\hline & & $\begin{array}{c}\text { HLFS (Mar01) } \\
\text { as \% } \\
\text { of Census (Mar01) }\end{array}$ & $\begin{array}{c}\text { HLFS (Mar01) } \\
\text { as \% } \\
\text { of Census (Mar01) }\end{array}$ & $\begin{array}{c}\text { HLFS (Mar01) } \\
\text { as \% } \\
\text { of Census (Mar01) }\end{array}$ & $\begin{array}{c}\text { HLFS (Mar01) } \\
\text { as \% } \\
\text { of Census (Mar01) }\end{array}$ \\
\hline $\begin{array}{l}\text { All New } \\
\text { Zealanders }\end{array}$ & & $101 \%$ & $105 \%$ & $78 \%$ & $39 \%$ \\
\hline By sex: & $\begin{array}{l}\text { Women } \\
\text { Men }\end{array}$ & $\begin{array}{l}100 \% \\
102 \%\end{array}$ & $\begin{array}{l}102 \% \\
107 \%\end{array}$ & $\begin{array}{l}71 \% \\
85 \% \\
\end{array}$ & $\begin{array}{l}46 \% \\
32 \%\end{array}$ \\
\hline By age band: & $\begin{array}{l}15-24 \text { year olds } \\
25-44 \text { year olds } \\
45-64 \text { year olds } \\
65+\text { year olds }\end{array}$ & $\begin{array}{l}105 \% \\
101 \% \\
101 \% \\
95 \% \\
\end{array}$ & $\begin{array}{l}108 \% \\
106 \% \\
104 \% \\
66 \% \\
\end{array}$ & $\begin{array}{l}78 \% \\
71 \% \\
94 \% \\
. . \\
\end{array}$ & \\
\hline By ethnicity $^{12}$ : & $\begin{array}{l}\text { European/Pakeha } \\
\text { Maori } \\
\text { Pacific Peoples }\end{array}$ & $\begin{array}{c}107 \% \\
89 \% \\
107 \%\end{array}$ & $\begin{array}{l}108 \% \\
88 \% \\
104 \%\end{array}$ & $\begin{array}{l}90 \% \\
60 \% \\
71 \%\end{array}$ & \\
\hline
\end{tabular}

Table 4: Statistics New Zealand estimates of labour market indicators: HLFS and SOFIE.

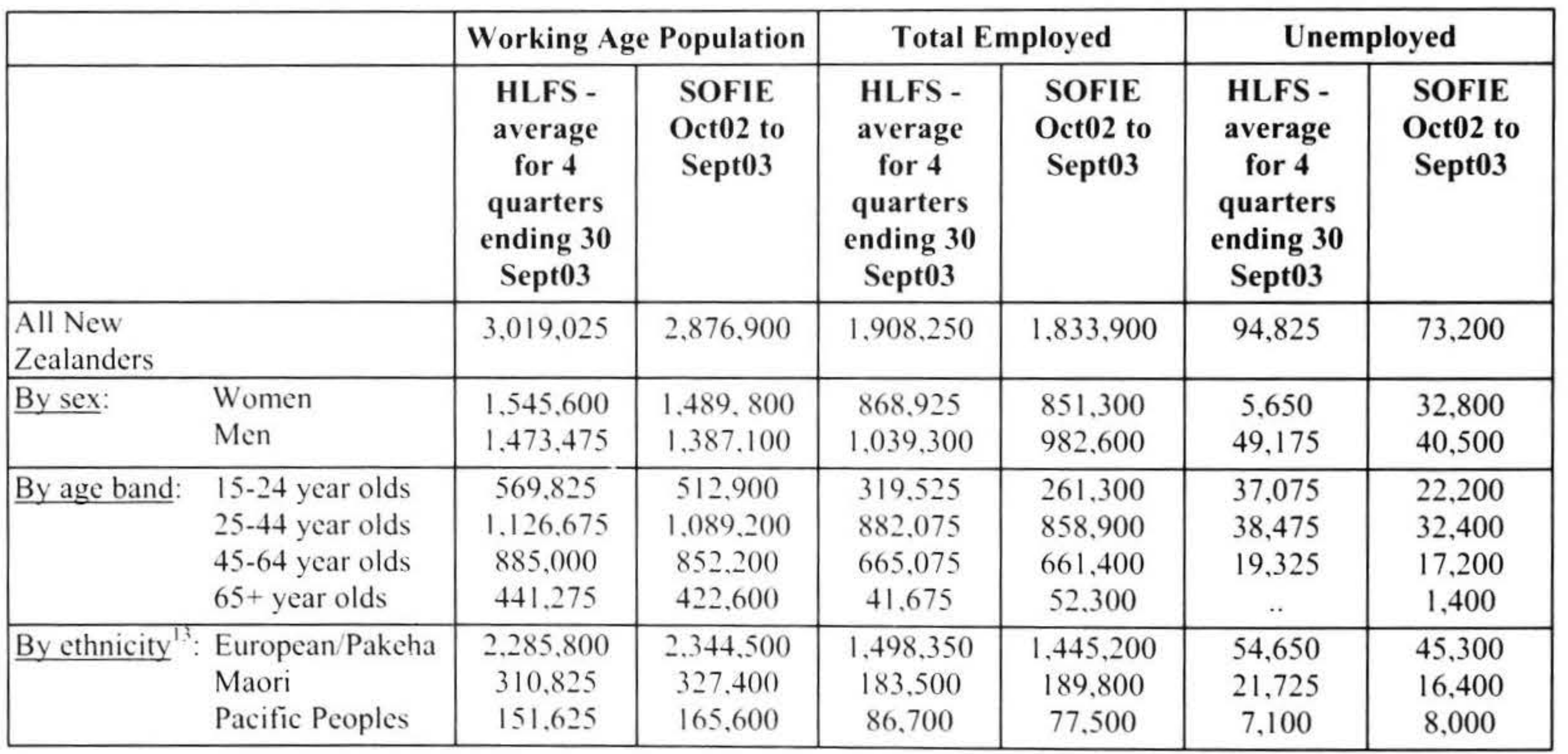

As the extent of disaggregation increases (e.g. into 4 age bands, or into four or more ethnicity categories), the risk of sampling error increases and the degree of comparability diminishes somewhat.

For indicators which apply to relatively minor proportions of the population, comparability diminishes substantially to the extent that it is difficult to reconcile Census-based and HLFS-based estimates. Table 6 summarises both quantitatively and qualitatively whether or not the indicator applies to the majority of the sampled population.

Table 5 suggests that different sample surveys, such as HLFS and SOFIE, can produce comparable results, at least for majority indicators and at the higher levels of aggregation. This reflects the efforts put into survey design, sampling and weights applied to raw data in the population estimates procedure. However, once again, as the level of disaggregation increases comparability can be affected even for the most universal indicator see Working Age Population by age band, or Total Employed by age band or ethnicity.

As for the comparison between Census and HLFS, the comparison between HLFS and SOFIE for a relatively minor labour market phenomenon, such as numbers unemployed, reveals a substantial difference in the estimates, even for all New Zealanders. The differences are even greater for particular age bands or ethnicities. 
Table 5: Comparing HLFS-based estimates with SOFIE-based estimates.

\begin{tabular}{|c|c|c|c|c|}
\hline & & Working Age Population & Total Employed & Unemployed \\
\hline & . & $\begin{array}{l}\text { SOFIE (Oct02/Sept03) } \\
\text { as \% of HLFS } \\
\text { (Ave,12months to } \\
\text { Sept03) }\end{array}$ & $\begin{array}{l}\text { SOFIE (Oct02/Sept03) } \\
\text { as \% of HLFS } \\
\text { (Ave,12months to } \\
\text { Sept03) }\end{array}$ & $\begin{array}{c}\text { SOFIE (Oct02/Sept03) } \\
\text { as \%of HLFS } \\
\text { (Ave,12months to } \\
\text { Sept03) }\end{array}$ \\
\hline $\begin{array}{l}\text { All New } \\
\text { Zealanders }\end{array}$ & & $95 \%$ & $96 \%$ & $77 \%$ \\
\hline By sex: & $\begin{array}{l}\text { Women } \\
\text { Men }\end{array}$ & $\begin{array}{l}96 \% \\
94 \%\end{array}$ & $\begin{array}{l}98 \% \\
95 \%\end{array}$ & $\begin{array}{l}72 \% \\
82 \%\end{array}$ \\
\hline By age band: & $\begin{array}{l}15-24 \text { year olds } \\
25-44 \text { year olds } \\
45-64 \text { year olds } \\
65+\text { year olds }\end{array}$ & $\begin{array}{l}90 \% \\
97 \% \\
96 \% \\
96 \%\end{array}$ & $\begin{array}{l}82 \% \\
97 \% \\
99 \% \\
125 \%\end{array}$ & $\begin{array}{c}60 \% \\
84 \% \\
89 \% \\
\quad . .\end{array}$ \\
\hline By ethnicity ${ }^{14}$ : & $\begin{array}{l}\text { European/Pakeha } \\
\text { Maori } \\
\text { Pacific Peoples }\end{array}$ & $\begin{array}{l}103 \% \\
105 \% \\
109 \%\end{array}$ & $\begin{array}{c}96 \% \\
103 \% \\
89 \%\end{array}$ & $\begin{array}{c}83 \% \\
75 \% \\
113 \%\end{array}$ \\
\hline
\end{tabular}

Table 6: Labour market indicator variable as a percentage of working age population, based on estimates from the census and HLFS at March 2001.

\begin{tabular}{|l|c|c|}
\hline Indicator variable & $\begin{array}{c}\text { \%of sampled population } \\
\text { based on HLFS estimates }\end{array}$ & $\begin{array}{c}\text { \%of sampled population } \\
\text { based on Census estimates }\end{array}$ \\
\hline Working Age Population & $\sim 100 \%$ & $\sim 100 \%$ \\
\hline Total Employed & $\begin{array}{c}62 \% \\
\text { majority }\end{array}$ & $\begin{array}{c}60 \% \\
\text { majority }\end{array}$ \\
\hline Numbers Unemployed & $\begin{array}{c}4 \% \\
\text { small minority }\end{array}$ & $\begin{array}{c}5 \% \\
\text { small minority }\end{array}$ \\
\hline Numbers of MJHers & $\begin{array}{c}2 \% \\
\text { small minority }\end{array}$ & $\begin{array}{c}6 \% \\
\text { small minority }\end{array}$ \\
\hline
\end{tabular}

Comparing time series data from HLFS (1986-2001) and Census $(86,91,96,01)$

The previous section focused on comparisons at a single point in time (March 2001) or over the same one-year period (October 2002 to September 2003). Monitoring, however, is about changes over time, so it is worth examining trends in data comparisons.

In this section we present graphically the comparison of data sets (Statistics New Zealand estimates) for Total Employed, Numbers Unemployed and Numbers of Multiple Job Holders between 1986 and 2004, taken from the HLFS and the Census, and supplemented with the one-off estimates from the Time Use Survey and SOFIE (Wave 1).

It has been suggested that some of the difference between the Census-based estimates and the HLFS-based estimates for Multiple Job Holding numbers might result from an apparent emphasis in the HLFS on wage and salary earners. Figure 4 repeats Figure 3 with the addition of Census-based estimates of the number of
Wage and Salary earners (first job) who have more than one job.

In Figure 1, the differences between Census-based estimates and HLFS-based estimates of Total Employed at each common point in time have remained constant, at $3-5 \%$. By contrast, the differences shown in Figure 2 between Census-based estimates and HLFS-based estimates of Numbers Unemployed have varied markedly at each common point in time, as summarised in Table 7. Figures 3 and 4 indicate a steadily increasing divergence between HLFS-based estimates of Multiple Job Holding and corresponding Census-based estimates.

\section{Discussion}

In this final section of our paper we recap the essential characteristics of our findings, elaborate on the social monitoring context which gives significance to the findings, discuss the implications for social monitoring of inconsistencies in official time series, and put up for further discussion a general proposition for resolving the issue. 
Figure 1: Total employed (000s) for all New Zealanders.

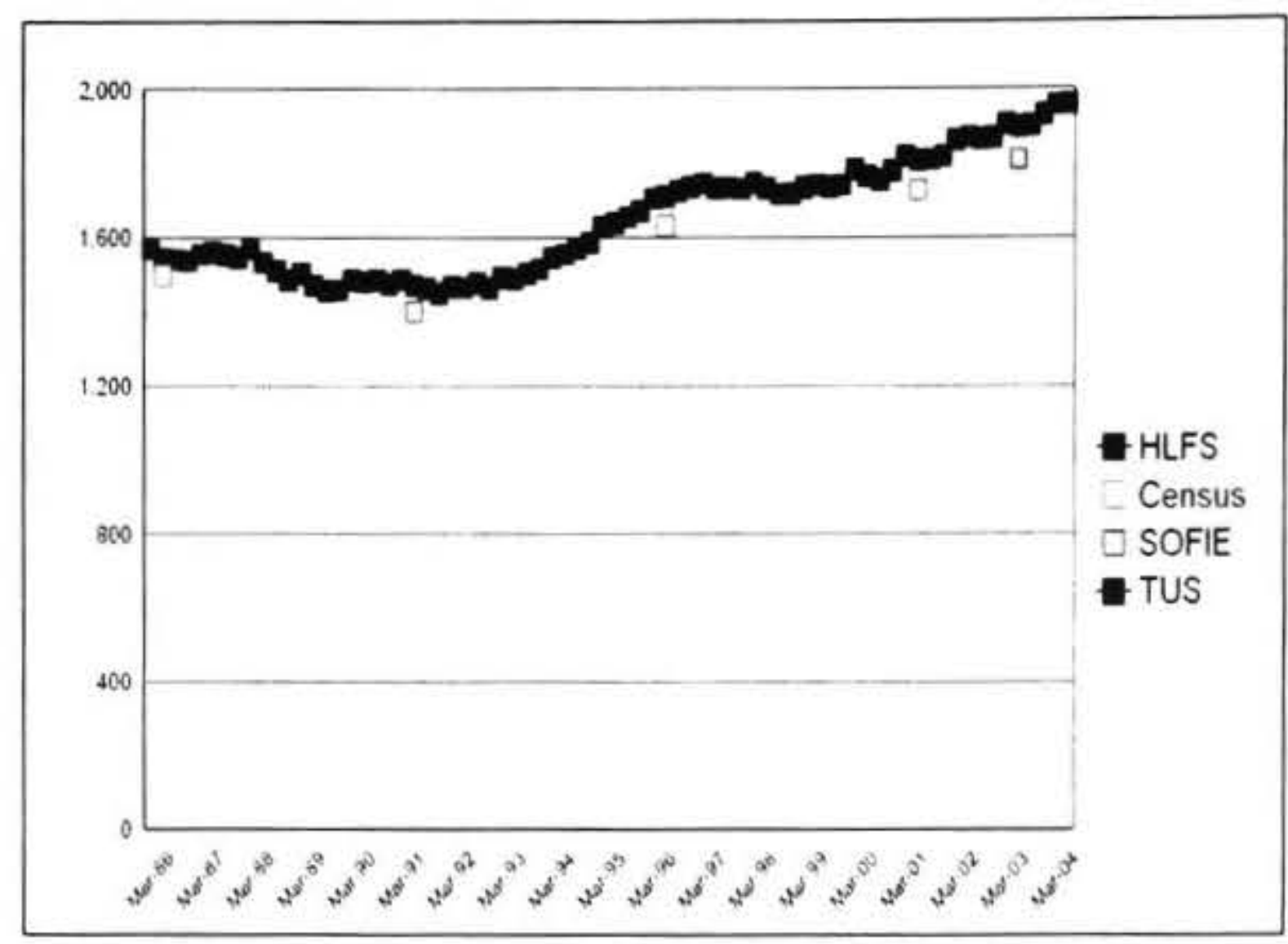

Figure 2: Numbers unemployed (000s) for all New Zealanders.

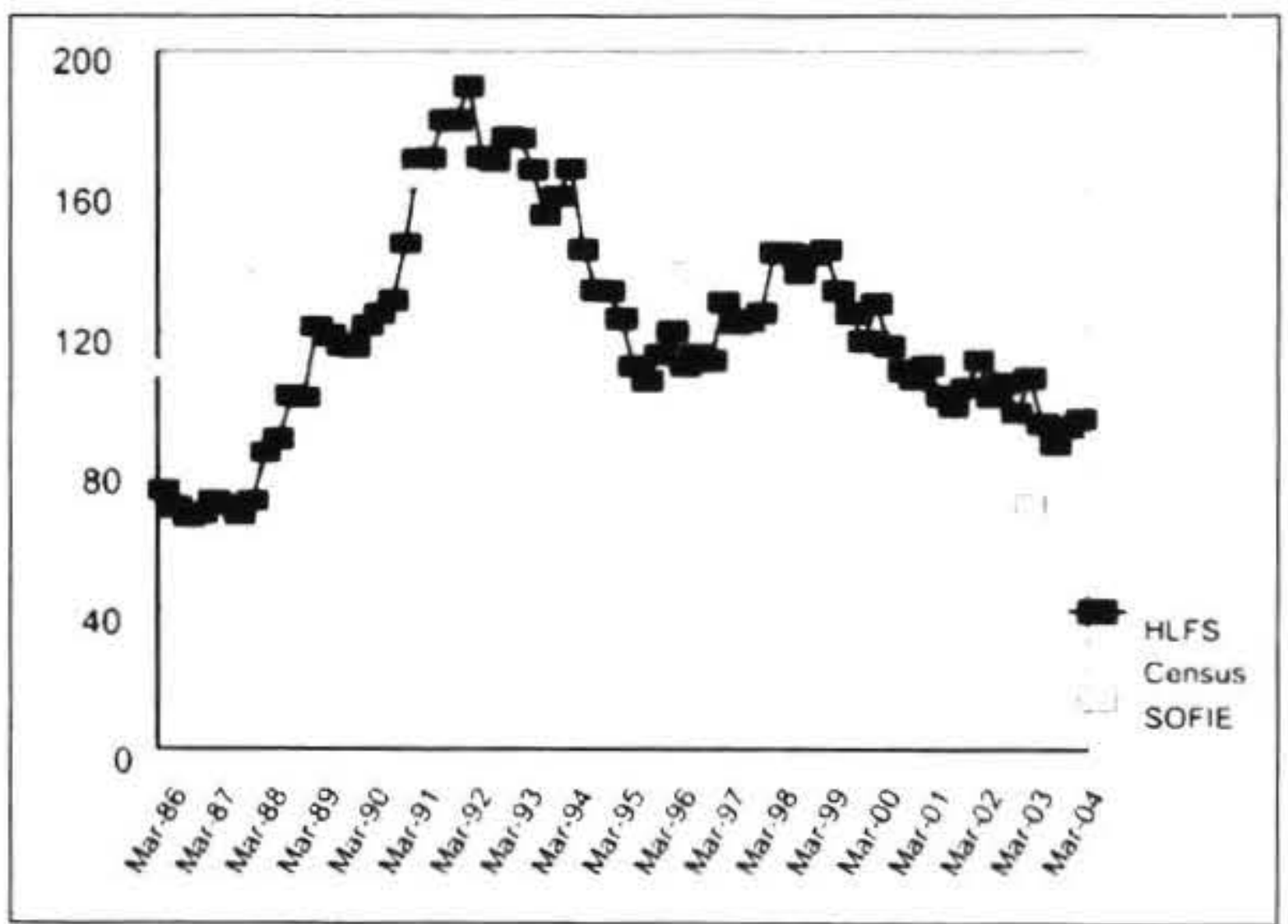

Figure 3: Numbers of multiple job holders (000s) for all New Zealanders.

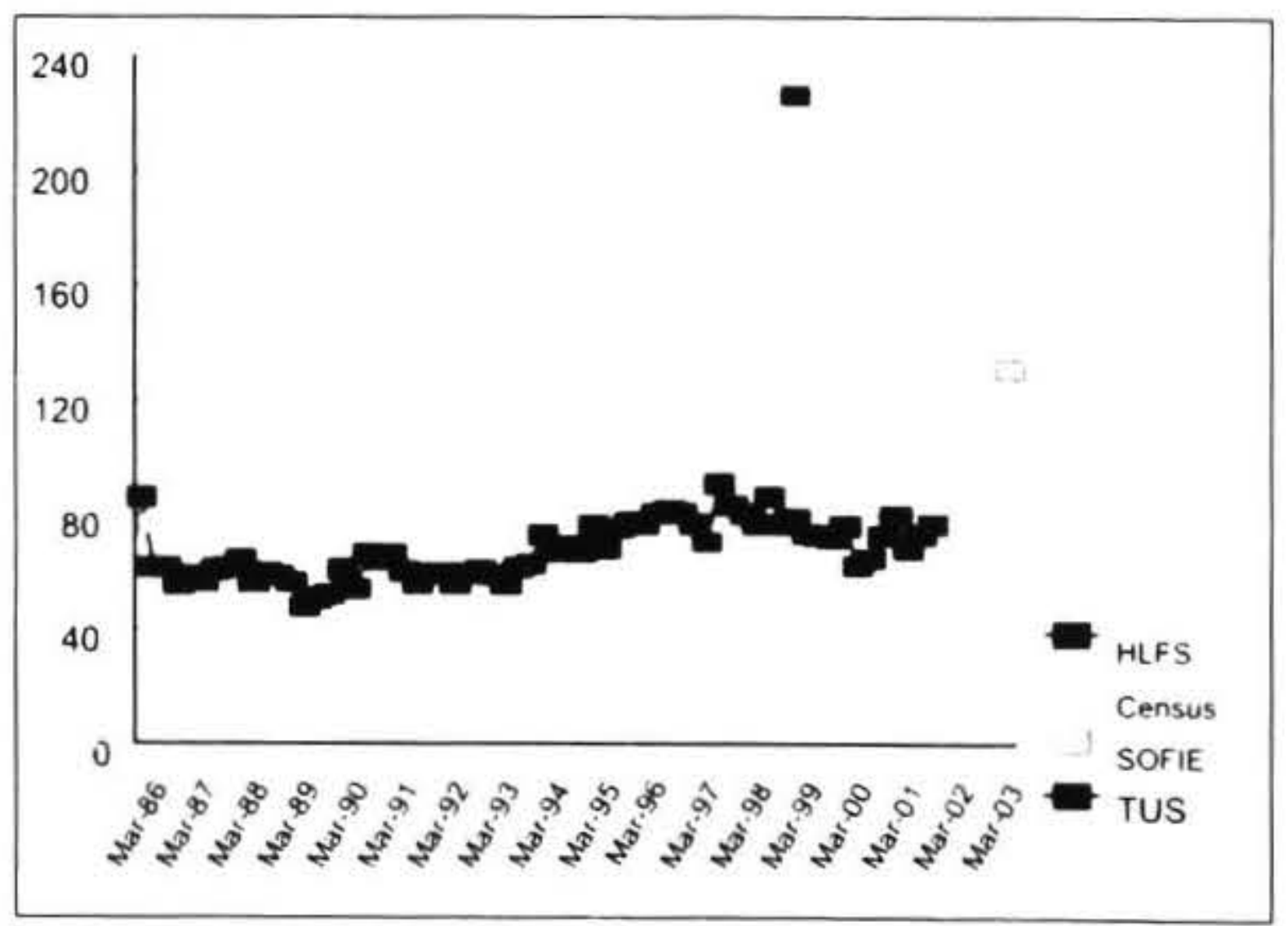

Figure 4: Numbers of multiple job holders (000s) for all New Zealanders.

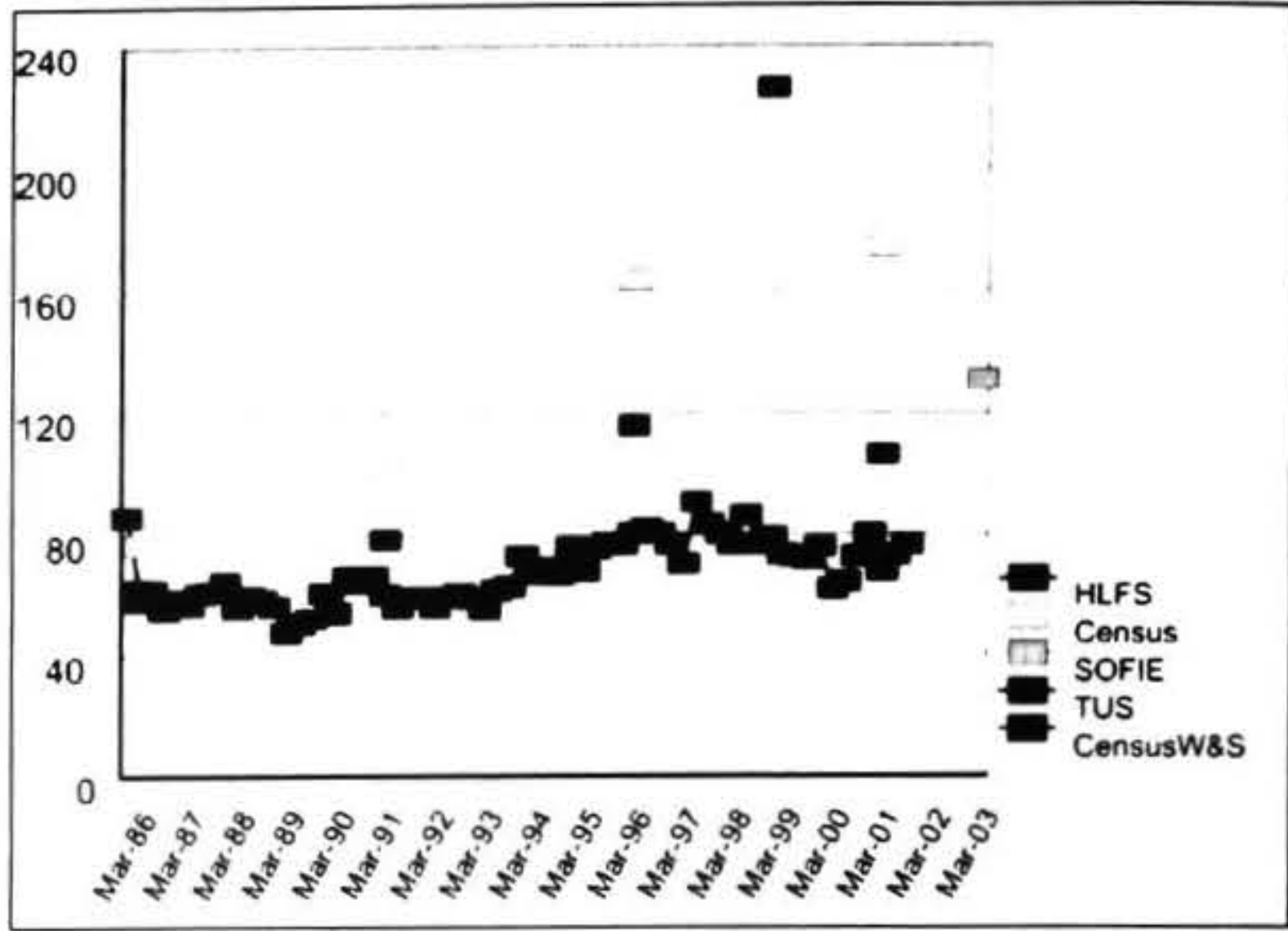

On the face of it, while highly aggregated indicators (Working Age Population and Total Employed) show reasonable comparability, there appear to be some substantial discrepancies between the various statistical estimates of the minority labour market indicators (Tables 2 and 4 ). This is the case for comparisons between the full Census and one sample survey (the HLFS) and for comparisons between two sample surveys (the HLFS and SOFIE).

There also appears to be a general trend that the discrepancies between the full Census and the HLFS for indicators of Unemployed and Multiple Job Holding have been increasing over time (Table 7). However, if the comparison for 1986 is included, this might suggest an element of randomness over time, perhaps as the composition of HLFS sample changes ${ }^{15}$.

The discrepancies between the two samples (HLFS and SOFIE) appear somewhat contradictory or random; SOFIE-based estimates for Numbers Unemployed are substantially less than the HLFS-based estimates (Figure 2) while SOFIE-based estimates for Numbers of Multiple Job Holders are substantially greater than HLFS-based estimates (Figure 3). While this is not necessarily surprising, it does beg the interesting question 'why?'

Finally, the HLFS-based estimates of Numbers of Multiple Job Holders are by far the lowest of all official estimates (Figure 3 ).

Social monitoring of labour markets is important for the development of policy interventions that seek to respond to the changing nature of work, or the evaluation of those same policy interventions. For most of those involved, unemployment is generally considered a transient labour force condition $^{16}$. Our qualitative research in multiple job holding sectors ${ }^{17}$ which are characterised by relatively low-income participants has also found that multiple job holding is not necessarily viewed as a permanent or desired labour force condition either. The emerging concept of sub-optimal employment ${ }^{1 \mathrm{x}}$ similarly applies to a relatively small proportion of people of working age. 
Table 7: Comparisons between HLFS-based estimates and census-based estimates over time.

\begin{tabular}{|l|c|c|c|c|}
\hline $\begin{array}{l}\text { HLFS-based estimate as a \% of Census-based } \\
\text { estimate for - }\end{array}$ & March 1986 & March 1991 & March 1996 & March 2001 \\
\hline Total Employed (Figure 1) & $103 \%$ & $105 \%$ & $105 \%$ & $105 \%$ \\
\hline Numbers Unemployed (Figure 2) & $68 \%$ & $103 \%$ & $88 \%$ & $79 \%$ \\
\hline Multiple Job Holders (Figure 3) & $80 \%$ & $59 \%$ & $49 \%$ & $39 \%$ \\
\hline Multiple Job Holders W\&S Only (Figure 4) & $106 \%$ & $77 \%$ & $69 \%$ & $64 \%$ \\
\hline
\end{tabular}

While policy interventions influencing any of these might seek to produce tangible results and trends within the short term, say six to twelve months, there are also labour market phenomena with trends and cycles which occur over much longer periods. The New Zealand official Unemployment Rate exceeded 5\% continuously over a period of more than a decade from the late 1980s to the late 1990s, and by either main statistical series (HLFS or Census) the numbers of multiple job holders increased by between $50 \%$ and $100 \%$ between 1986 and 1996. Longer time frames are also important for monitoring change. This has been demonstrated in Judith Davey's research in the 'Birth to Death' series ${ }^{19}$

Effective social monitoring requires the essential characteristic of distinguishing the experience of particular groups in society; in other words, social monitoring is by definition disaggregated monitoring. The Social Monitoring Framework first developed in the 1970 s and 1980s in this country, and referred to previously by Davey, required accurate disaggregation of indicators by sex, age group and ethnicity. Researchers like Callister and Newell ${ }^{20}$ have taken such life-stage related disaggregation to a new level with their birth cohort history analysis, the principles of which are reflected in longitudinal surveys like the SOFIE.

\section{Implications}

The answer to this question depends on the explanation for the differences. However, the magnitude of the differences is large enough to have implications for policy work and for associated programme costings.

We have attempted to explain some of the differences between the Census and the HLFS in previous work ${ }^{21}$. When comparing estimates of multiple job holding rates, we accounted for differences in the wording of questions and in the sample frame, and still concluded that HLFS data accounts for less than half $(46 \%)$ the multiple job holders recorded in the census.

Thus there is likely to be a need to adjust the results from one or more of these statistical sources. A simple crude solution would be to benchmark the least reliable source to the most reliable. A more satisfactory but more complex, more labour intensive and expensive solution would be to adjust all raw results for known response rate and sample bias.

\section{Improvements}

Firstly, we note that Statistics New Zealand use the same sampling frame for all the sub-population surveys mentioned here - the HLFS, SOFIE and the Time Use Survey. Hence discussion in terms of one such survey (e.g. the HLFS) is probably equally applicable to these other surveys. That being said, there are important differences in survey implementation mode between these three: the HLFS begins with a face-to-face interview, but follow-up interviews are carried out by telephone; the SOFIE is carried out face-to-face each time; the TUS was carried out using face-to-face interviews.

The differences between HLFS and census estimates of Unemployment and Multiple Job Holding exceed undercount errors in the census by an order of magnitude. The HLFS is a survey and so all results have implicit assumptions on sampling and weighting requirements to arrive at national and regional estimates.

The Census is a census aiming to cover the whole population and has a relatively small undercount, so traditionally few applications have needed to adjust the census for net undercount. However, where the undercount for one census is markedly larger than for the previous census, as was the case in $2001^{22}$, then adjusted estimates are likely to be important for some time series applications.

What the HLFS results presented here suggest is a drift away from a fully representative national population estimate for marginal phenomena observed in low income and at risk sub-populations, or in other groups equally difficult to reach, such as high-income multiple job holders working exceptionally long hours.

The HLFS is one of the oldest quarterly surveys and it may be that the survey has not kept pace with changes in the assumptions implicit in the sampling, sample weightings and adjustments to response rates. For example, followup interviews are done by telephone survey. If a group is becoming harder to contact by landline telephone over time, this could introduce a systematic bias in the results over time?

In considering what might be done to resolve the issue of substantial discrepancies between estimates of minority phenomena - but still important phenomena ${ }^{23}$ - from 
different statistical sources, the relative reliability of the different sources must be judged.

Even though the Census is not the primary labour market monitoring instrument, because of its five-yearly periodicity, it has, by definition, the lowest level of sampling error. However, we note that even the Census is not without sampling errors. Traditionally, little need has been seen to adjust the census for net undercount, but as the applications of the Census results have grown more sophisticated and assumed more precision, the need has been shown to adjust for Census net undercount ${ }^{24}$. For birth cohort life history analyses, using individual variables from the census, it is necessary to factor in a range of adjustments to improve comparability between successive census results. The range of issues involved includes scaling estimates to allocate missing value categories, adjustments for official and intercensal drift in classifications, and in some cases filtering for noise arising from coding errors for individual variables. The proportion of official missing value, non-imputed values varies greatly but is often large. These have been key issues in the time series development for the FRST multiple job holding programme.

Nevertheless, we suggest that the Census remains the most robust source of labour market data. whether aggregated or disaggregated.

For linking other sub-population survey results with the Census, some form of bench marking is required. We note that this already occurs for the HLFS, where the weighting factors used in making population or subpopulation-based estimates have regularly been adjusted after each new census is published ${ }^{2}$. It is perhaps in the weighting and estimation procedures that changes might be possible. which would improve the comparability of disaggregated, sub-population estimates between surveys and the Census.

\section{Conclusions}

A fresh appraisal of the compatibility of different soures of statistical data on labour market phenomena is required in order to give confidence to the use of such data for social monitoring purposes. A robust approach to social monitoring relating to the future of work. linking longitudinal and cross-sectional detail, depends on our ability to achieve far greater coherency of estimates for sub-populations and minority but nevertheless important labour market phenomena.

\section{Notes}

The research is funded by the Foundation for Research, Science and Technology, contract TBAX0204.

A complete listing of Working Papers and Conference papers can be found at www.tba.co.nz example of this.

Davey (2006, In Press, p.2) reminds us that the Social Development Council, established in 1971, developed a set of social objectives 'centred on the goals of increased opportunity, more equality and greater social well being'.

A surrogate for 'significant life events' (Davey, 2006, In Press, p.4)

SOFIE-based estimates have been sourced from published data as well as data supplied to Taylor Baines \& Associates on request.

A sampling rate of approximately 1 in 100 eligible individuals.

9 Available online: www2.stats.govt.nz/domino/external/omni/omni .nsf/outputs/Household+Labour+Force+Survey

10 Available online: www.stats.govt.nz/products-and-services/info -releases/SOFIE-info-releases.htm

11 Statistics New Zealand state that these data have been suppressed because they are subject to sampling error too great for most practical purposes.

12 Only major categories included; more categories exist.

13 SOFIE estimates disaggregated by ethnicity allow for multiple responses from individuals of mixed ethnicity; total number of responses $=3,089,100$ compared with $2,876,900$ individuals, i.e. $-7 \%$ multiple responses.

14 See previous endnote.

15 Each quarter, one-eighth of the total sample of houscholds is replaced, and households remain in the survey for two years (i.e. eight quarters).

16 Although it is acknowledged that there are individuals and households in New Zealand which already experience inter-generational unemployment.

17 Such as the Café and Restaurant Sector (Taylor Baines \& Associates Working Paper \#7, June 2004) and Creative Sector (Taylor Baines \& Associates Working Paper \#14, June 2006) http://www.tba.co.nz/frst_projects/frstproject_tbsx 0204.html; also Osborne, R and Warren, J 2006. Multiple Job Holding - a Working Option for Young People, paper presented at 12th Labour, Employment and Work Conference, Wellington, November 2006. 
As discussed in another paper presented at this conference by Dupuis, A and Taylor, $\mathrm{CN}$ entitled "A Framework for Examining Sub-Optimal Employment”.

19 Davey, J. 2003. Two Decades of Change in New Zealand : From Birth to Death V, Institute of Policy Studies, Victoria University of Wellington.

20 See, for example, Callister, P. (2006) Are New Zealanders heading for older age richer, better educated and more likely to be employed? In J. Boston and J. Davey, Implications of Population Ageing: Opportunities and Risks, Wellington: Institute of Policy Studies; and Newell, J. and M. Perry (2006) Trends in the contribution of tertiary education to the accumulation of educational capital in New Zealand: 1981 to 2001, report prepared for the Ministry of Education, Wellington: Monitoring and Evaluation Research Associates Ltd www.educationcounts.edcentre.govt.nz/publicatio $\mathrm{ns} /$ tertiary/contribution-tertiary $81-01 . \mathrm{html}$

See Baines, JT, Newell, JO and Taylor, CN 2006. Multiple Job Holding: comparison of data from the Household Labour Force Survey and the Census. Working Paper 12, funded by FRST Research Project TBAX0204. Taylor Baines and Associates April 2006.

The estimates "A Report on the Post-enumeration Survey 2001", Statistics New Zealand 20023 estimatedimply that the 2001 census had a 25,000 larger net undercount than the 1996 census.

Recall that one of the prime functions of the HLFS is to provide up-to-date monitoring of the numbers Unemployed.

See, for example, Newell, JO 2004 where he showed that school roll projections were improved when account was taken of census undercount in the 2001 starting year population estimates.

Refer to 'Guide to Interpreting Data' in: www2.stats.govt.nz/domino/external/omni/omni .nsf/outputs/Household+Labour+Force+Survey\#G

\section{References}

Baines, J. and Newell, J. (2003). A Profile of Multiple Job Holding in New Zealand Based on 2001 Census Data. Working Paper No.2. Christchurch: Taylor Baines \& Associates.

Baines, J., Newell, J. and Morgan, B. (2005). Multiple Job Holding Data from the Time Use Survey 1998/99. Working Paper No.9. Christchurch: Taylor Baines \& Associates.

Baines, J. and Newell, J. (2005). Trends in the New Zealand Labour Market, Non-Standard Work and Multiple Job Holding 1981-2001. Working Paper No.11. Christchurch: Taylor Baines \& Associates.

Baines, J., Newell, J. and Taylor, C. (2006). Multiple Job Holding: Comparison of Data from the Household Labour Force Survey and the Census. Working Paper No.12. Christchurch: Taylor Baines \& Associates.

Davey, J. (2006). From Birth to Death: A Social Monitoring Framework from New Zealand. Wellington: Victoria University of Wellington (In Press)

\section{Authors}

James Baines

Director

Taylor Baines \& Associates

P.O. Box 860

Riccarton

Christchurch

J.Baines@tba.co.nz

James Newell

Director

Monitoring and Evaluation Research Associates Ltd

P.O. Box 2445

Wellington

Jnewell@mera.co.nz 